man's 'stream of consciousness', struggling with sentences which, as the translator feelingly says, are 'among the longest in literature', written in a style which is fantastically Teutonic and a syntax which, according to Herr Broch, is "purely functional', whatever that may mean. Virgil has a lucid interval towards the middle of the book and his conversation with Augustus is comparatively easy reading. We get some unexpected sidelights on Roman literary life and are gratified to learn that Virgil is a good anti-Nazi. The improvement unfortunately does not last. Virgil relapses into a delirium which continues almost unbroken until page 482.

Some idea of the book's quality will be gathered from the following extract. 'Layer on layer, one above the other, the bareness of a no-heaven was covered by the round bow of the bay-window, both arching over the sepulchre, both permeated by un-space even though shot through by the velvet blackness of the whole star-studded round of the sky, and the domes of the universe were intergrown by elms in an immeasurable expansion of all discrepancies and distances which, at the same time, was an immeasurable contraction of them; the landscape-lack pierced the landscape and was pierced by it, symbolic in its lack of symbol, just as the animal element penetrated the trance-death and was penetrated by it in turn ...'

Herr Broch's work may appeal to a certain number of readers who have not had a classical education.

\section{University of Edinburgh.}

\title{
CORRESPONDENCE
}

Sirs,

In C.R. lxi, p. 57, Professor Hackforth dismisses as 'absurd' the generally accepted rendering of

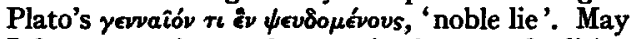
I draw attention to the note in the second edition of my Aeschylus and Athens, pp. 453-4, in which, after an examination of the word yevvaios and a

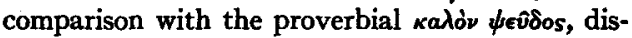
cussed in my edition of the Oresteia (vol. ii, pp. 73-4), the conclusion is reached that this expression is an oxymoron of the normal type and that the meaning can only be 'noble lie'?

$$
\text { Yours truly }
$$

Grorge Thomson.

\section{Dear Sirs,}

Leake in his Travels in the Morea, i, p. 449, has an interesting account of a boat in use in his day. The gunwales were enveloped in withies 'to protect it from the waves or from danger of a sudden heel'. This is a curious and telling commentary on the boat built by Odysseus with Calypso's help (Od. v. 233 ff.), when 'he fenced it with wattled osier withies from stem to stern, to be a bulwark against the wave, and piled up wood to back them'. Leake is well worth reading, although he seems largely to be forgotten to-day.

\section{Yours truly}

H. Micheld.

Macmaster University.

\section{SUMMARIES OF PERIODICALS}

\section{CLASSICAL PHILOLOGY}

\section{3 : JULY, 1947}

E. J. Bickerman, Apocryphal Correspondence of Pyrrhus: examines the letters exchanged between P. and Laevinus in Dion. Hal. A.R. xix.9-10; from opening formulae concludes that D.'s authority was a Roman annalist writing in Greek between 170 and 120, probably Acilius; from the contents of $P$.'s letter that it is based on a genuine one of 280 B.C., but coloured by later experience of Greeks. E. H. Haight, Menander at the Sabine Farm: sees the influence of Menander on Horace in the dramatic form of the Satires. G. Vlastos, Equality and Justice in Early Greek Cosmogonies: the preSocratics make the assumption that equality is the guarantee of cosmic justice or harmony. H. W. Miller, The Parabasis of the Thesmophoriazusae of Aristophanes: suggests that A. got the idea from the defence of women in Euripides' Melanippe Desmotis. C. A. Lynch, Agamemnon 1323-6: defends the manuscript reading (with Jacobs's $\eta \lambda(0 v)$ - I pray that the avengers of my death may make retribution along with my murderers': only with the final o $\mu_{0} 0$ doe's the audience realize that Cassandra is cursing Orestes as well as Clytae- mnestra. B. D. Meritt, Honours to Faustina at Corinth: confirms West's suggestion that the inscription recording honours to $\mathrm{F}$. (Corinth, viii. 2, no. 22) was that mentioned by Wheler and gives a fuller version based on Wheler's notes (B.M. Add. 35334) made before the stone was mutilated. $R$. H. Crum on Petronius 42. 6-7 proposes (feminam) neminem.

\section{4 : OCTOBER, 1947}

B. B. Boyer, Insular Contribution to Mediaeval Literary Tradition of the Continent (I): notes on the tradition of Ps.-Cyprian, De xii abusivis saeculi,

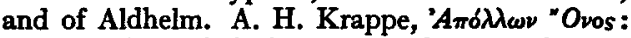
the tradition (Pind. $P$. x. $3^{\mathrm{I}-6)}$ ) of a Hyperborean cult of Apollo with sacrifice of donkeys and the legends of Marsyas and Midas point to an Anatolian cult of an ass-god, identified with Apollo, which was brought by northern invaders from the Danubian region. W. K. Pritchett, Julian Dates and Greek Calendars: concludes that 'the calendric basis for temple-orientation' is too uncertain to give reliable results. E. E. Burriss, Breaks in Conversation and the Text of Petronius: several emendations and suppletions are rendered unnecessary by the supposition of aposiopesis or broken 